\title{
FINANCIAL ANALYSIS OF FOREIGN DIRECT INVESTMENT ON ECONOMIC GROWTH OF DEVELOPING COUNTRIES
}

\author{
Božidar Raičević ${ }^{1}$, Svetlana Ignjatijević2 ${ }^{2}$ Ivan Milojević3
}

\begin{abstract}
The object of the research paper is to perform an empirical analysis of foreign direct investment (FDI) influence on economic growth with the aim of establishing factors that will contribute to overcoming the problem. The research results imply that realistic exchange rate, export and import as well as state expenditures are statistically significant for predicting economic growth movement and they have a positive influence on FDI movement. Empirical analysis, contrary to expectations, has shown that FDI, public debt and openness have a negative impact on economic growth in the case of Republic of Serbia. In the following period Serbia has to decrease the share of budget deficit in GDP and control public debt. Serbia has to pay special attention to improving investment environment and encourage export oriented production, whereas finance management and continuation of reform processes are the basis for establishing sustainable development of country, with sustainable use of available resources.
\end{abstract}

Keywords: foreign direct investment, economic growth, export, Republic of Serbia, sustainable development

JEL: $Q 10, F 21$

\section{Introduction}

By foreign direct investment it is implied that investors from one country invest in another country. In the process an investor gains control over the management in the company in which the resources have been invested. Foreign direct investments ensure product placement, technology export, placement of managerial knowledge

1 Božidar Raičević, Ph.D., Professor emeritus, Slobomir P University, Svetog Save street no. 1, Doboj, BiH, E-mail: boskoraicevic@gmail.com

2 Svetlana Ignjatijević Ph.D., Associate Professor, Faculty of Economics and Engineering Management in Novi Sad, Cvećarska Street no. 2, 21000 Novi Sad, The Republic of Serbia, E-Mail: ceca@,fimek.edu.rs

3 Ivan Milojević Ph.D., Full Professor, University of Defense, Military Academy, Pavla Jurišića Šturma Street no. 33, 11000 Belgrade, The Republic of Serbia, Phone: +381 606699 177, E-Mail: drimilojevic@gmail.com

EP 2016 (63) 2 (649-663) 
and experience, expansion to the markets of capital importing countries, using natural resources and costs saving. In recent years FDIs have been directed towards developing countries and countries in transition, since privatization processes in them ended or they are coming to an end. In order to achieve faster economic growth, beside stimulating the capital of international financial institutions, it is necessary to stimulate FD inflow into production activities which will stabilize the economy and increase export. Apart from the expected economic growth, salaries and employment, FDI should contribute to tax income increase, development of technical and managerial abilities as well as competition increase. What foreign investors find attractive are a relatively high purchase power of the market, favourable infrastructure and especially, cheap though qualified labour force. These countries are intensifying their participation in international trade, the increase in export and import in GDP is also present, which facilitates FDI inflow.

Due to privatization in Serbia, FDIs have been on the increase since 2001. In 2006 their growth reached the maximum of $\$ 4,286$ million, which coincided with a high rate of investment increase in the region. In 2011 investments amounted to \$2,142 million, out of which $39.5 \%$ was invested in wholesale and retail trade, $21.1 \%$ in processing industry, $11.1 \%$ in financial activities and insurance and $6.9 \%$ in real estate business. In the period between 2001 and 2010 the largest investors were the companies Telenor with $€ 1,602$ million investment in the field of communications, Gazprom Neft with $€ 947$ million in oil and gas industry and Fiat with $€ 940$ million in automobile industry. The economic growth in recent years has been characterized by insufficient FDI inflow and its low participation in GDP.

Numerous studies have been dedicated to the significance of FDI for economic growth and they emphasize the influence of FDI on export increase and natural resources exploitation. Cuadros et al. (2004) point out positive and negative influences of FDI, while Chowdhury, Mavrotas (2006) emphasize that positive influence is generally expected owing to human capital and productivity level. The studies of FDI influence on economic growth have been analysed by some authors at micro or macro level and precisely Carkovic, Levine (2002) indicate positive FDI results at macro level. When it comes to FDI and export correlation, Marchant et al. (2002) imply substituting effect, while Graham (1997) implies complementary relationship between FDI and export. In that context the aim of this paper is to examine the influence of FDI on economic growth. Empirical analysis should answer the question which factors contribute to FDI growth and how investment inflow is reflected in GDP increase.

\section{Literature Overview}

Graham, Wada (2002) analysed FDI inflow in China. The investment inflow from Japan, Europe and North America was on the increase. They stated that FDI encouraged income growth. Blomstrom, Kokko (2003) analysed the effect of investment incentives and specified that benefits are present for local companies if they are capable and motivated to apply foreign technology and skills. Investing in learning and management 
development is required and investments will contribute to the increase in employment, export and tax income. The focus is on the usage of investment incentives for foreign companies. They concluded that these incentives were not efficient in terms of improving national well-being. Instead of investment policy defined in this way, they suggest a package of investment incentives for complete industrial policy, equal incentives for domestic and foreign investors, incentives for investments that connect domestic and foreign companies, education, and training about R\&D.

Choe (2003) explored the causal connection between economic growth and FDI. A strong kao positive connection between these two elements was proven. Numerous studies have focused on the economic growth research from the aspect of long-term inflow of FDI and GDI rates (gross domestic investment). However, the positive correlation does not confirm that high FDI and GDI rates result in heightened inflow or vice versa.

Brock (2005) examined the influence of FDI on regional economic growth. He emphasized the limited effect of FDI on the growth of domestic companies due to limited reforms of institutions, judicial reforms, etc. Chowdhury, Mavrotas (2006) examined the relation between FDI and economic growth. The relation studied was the one between growth determinant, FDI determinant, the role of multination companies in the host country and the causality direction. The authors emphasized that FDI added on domestic investments and affected employment, technology transfer and overall economic growth. Empirical study proved unidirectional or mutual connection between FDI and GDP.

The results of the study performed by Nunnenkamp, Schweickert, Wiebelt (2007) imply that FDI inflow increases economic growth and decreases poverty. They concluded that FDI contributes to differences between cities and rural areas. The growth and employment can be limited so the state needs to strengthen economic capacities, while public investment can contribute to overcoming bottlenecks in infrastructure.

The data of the empirical research by Asiedu (2006) suggest that macroeconomic instability, limited investment, corruption and political instability affect FDI negatively. The paper analysed the significance of natural resources, market size and the power of institutions to direct FDI inflows. Good infrastructure, natural resources, low inflation and efficient judicial system have a positive influence. Nevertheless, it is also pointed out that a country which lacks natural resources can attract FDI through the improvement of institutions. The IMF and the World Bank can contribute to FDI inflow as well.

Hansen, Rand (2006) emphasize that FDI inflow can have a positive influence on the economic growth of a country only if a minimum of educational, technological and infrastructural level of development is achieved. The question is whether FDI contributes to long-term growth and development or the accelerated economic growth attracts investments of transnational companies searching for new markets and profit.

Bengoa, Sanchez-Robles (2003) explored the connection between economic freedom, 
FDI and economic growth. The research proved the significance of government engagement in achieving political and economic stability and market-oriented economy. Economic freedom increase should be politics' priority.

The influence of FDI on economic growth was examined by Carkovic, Levine (2002). Positive effect of FDI and portfolio inflow is a result of technology transfer. They proved that FDI inflow does not affect economic growth independently.

In their study Hermes, Lensink (2003) examined the role of financial system in strengthening positive effect of FDI on economic growth. They investigated the level at which FDIs can improve technological change through the inflow of knowledge and new capital goods. Authors claim that financial system development of FDI receiver is essential for positive influence of FDI on economic growth.

Chen, Chang and Zhang (1995) ascertained that FDIs influenced economic growth positively. The opening of Chinese economy is a constant process and it is necessary to establish the contribution to the success of most recent economic reforms. In a similar study Asiedu (2006) suggested that macroeconomic instability, investment limits, corruption and political instability had a negative influence on FDI in Africa. The significance of natural resources and market size, government policy and institutions of the host country in directing FDI were also analysed. The results of the research show that inflation decrease, good infrastructure, educated population, openness for foreign direct investment, lower level of corruption, political stability and reliable legal system have a positive effect on attracting FDI.

Raičević and Ignjatijević (2001) indicated that natural resources can be an invaluable advantage for more substantial FDIs in the sphere of tourism. FDIs need to be directed towards reconstruction, revitalization and building new modern capacities, the application of modern information technologies and modern marketing concepts, management concepts and promotional activities as well as raising the level of tourism services quality. Ignjatijević et al. (2015) indicated that "if we start from the fact that the goal of every company is long-term survival, profitability, cost effectiveness and positive financial results, it is clear that companies must continually work on sustainable development of trade by applying new technologies for management".

\section{Methods}

In the paper we use regression analysis in order to examine empirical relationship between FDI and economic growth. As we can see, numerous authors have explored the mentioned relationship and defined several indicators. Our intention is to perceive the aspects relevant for Serbian economy. One of the basic variables is GDP per capita, which is at the same time an indicator of market size (Cannonier et al., 2007) or market development (Kolstad and Villanger, 2004). As a measurement of non-exchangeable goods and imported goods we used realistic exchange rate. Inflation rate is a significant macroeconomic indicator; a share in the sum of export and import in GDP is an indicator of economy openness, while public consumption share in GDP is the indicator of the 
government role. It is logical to expect that an increase in FDI inflow will affect the decline in public finance from privatization (Flexner, 2000). We will mention another direct influence of GDP growth rate in the world. We refer to the position of Kolstad and Villanger (2004) on the relevance of the method applied.

In our paper we used the data of Statistical Office of the Republic of Serbia, World Bank and IMF for the period between 2001 and 2011. Following the example of Cannonier et al. (2007) we used natural algorithms of all values and STATA economic software.

In our theoretical research we used the following model:

$$
\begin{aligned}
& F D I=\alpha_{0}+\alpha_{1} G D P_{i t}+\alpha_{2} D E B T_{i t}+\alpha_{3} E X P_{i t}+\alpha_{4} R E R_{i t}+\alpha_{5} I N F_{i t}+ \\
& \alpha_{6} G O V_{i t}+\alpha_{7} I M P_{i t}+\alpha_{8} W G D P_{i t}+\alpha_{10} I M P E X P_{i t}+\varepsilon_{i t}
\end{aligned}
$$

in which $\mathrm{j}$ indicates country and $\mathrm{t}$ stands for time period.

$$
\begin{aligned}
& G D P=\beta_{0}+\beta_{1} F D I_{i t}+\beta_{2} D E B T_{i t}+\beta_{3} E X P_{i t}+\beta_{4} G O V_{i t}+ \\
& \beta_{5} W G D P_{i t}+\beta_{6} I M P_{i t}+\beta_{7} I M P E X P_{i t}+\beta_{8} R E R_{i t}+\beta_{9} I N F L+\varepsilon_{i t}
\end{aligned}
$$

where:

GDP $=$ Domestic Real GDP per capita; IMP= Imports of goods and services to GDP; $\mathrm{RER}=$ Real exchange Rate (EC\$ per US\$); EXP= Exports of goods and services to GDP; INFL = Inflation rates; DEBT $=$ External Debt to GDP; IMPEXP = Imports plus Exports of goods and services to GDP; GOV= Central Government expenditure to GDP; FDI = Foreign direct inflows per capita; WGDP= World Growth in GDP; $\varepsilon=$ Stochastic Error Terms; Where, $\alpha$ and $\beta$ are the respective parameters.

\section{Results and discussion}

The most common mode of foreign capital inflow in Serbia is in the form of buying domestic companies or banks. Considering that Serbian economy is characterized by low cumulative capability, minimal savings FDI gain in importance. For Serbia as well as all countries in transition foreign direct investments which would set country's economic growth in motion are necessary. In the period between 2006 and 2010 a significant decline in FDI inflow was noted, which had a negative impact on introducing new production capacities, unemployment and export growth, finally resulting in country's economic growth downtrend. According to UNCTAD data, Serbia has received \$16 billion in the last 10 years and if we observe a longer time period (1995-2010) \$21.5 billion of foreign direct investments. In recent years a negative downward trend of FDI decline has been present. In 2006 FDIs amounted to $\$ 4.3$ billion and in 2010 it was $\$ 800$ million. The analysis has shown that the share of European countries' investment is dominant, followed by lower amount of investments coming from the USA. 
FDI share in total investments at the world level is significantly lower even when compared to transition countries, and especially considering developed European economies. A large number of factors affect FDI movement direction and the level of investment. Uncertainty among investors certainly conditioned FDI moderation and oscillations. Different level of FDIs was probably affected by levels of technological development, efficiency as well as business productivity. The size and level of public sector, the structure of industrial production, geographic position and the level of development of human capital are just a few more determinants of FDI attraction (Praća, 2015). If we perceive the large difference in the FDI levels in Serbia and developed countries it is clear that balanced politics, macroeconomic stability, corruption, institutional disorder are actually a limiting factor for FDI attraction - Table 1.

Table 1. US Dollars at current prices and current exchange rates in millions, US Dollars at current prices and current exchange rates per capita and Percentage of total world

\begin{tabular}{|c|c|c|c|c|}
\hline \multicolumn{2}{|c|}{} & 2000 & 2005 & 2011 \\
\hline \multirow{4}{*}{$\begin{array}{c}\text { US Dollars at } \\
\text { current prices and } \\
\text { current exchange } \\
\text { rates in millions }\end{array}$} & Serbia & - & - & $2,709.27$ \\
\cline { 2 - 5 } & Serbia and Montenegro* & 51.78 & $2,077.65$ & - \\
\cline { 2 - 5 } & $\begin{array}{c}\text { Transition economies } \\
\text { Europe }\end{array}$ & $7,038.38$ & $30,853.96$ & $92,162.89$ \\
\hline \multirow{3}{*}{$\begin{array}{c}\text { US Dollars at } \\
\text { current prices and } \\
\text { current exchange } \\
\text { rates per capita }\end{array}$} & Serbia & - & - & 274.94 \\
\cline { 2 - 5 } & Serbia and Montenegro & 4.81 & 198.19 & - \\
\cline { 2 - 5 } & $\begin{array}{c}\text { Dransition economies } \\
\text { Europed economies: }\end{array}$ & 23.06 & 102.25 & 303.95 \\
\hline \multirow{4}{*}{$\begin{array}{c}\text { Percentage of } \\
\text { total world }\end{array}$} & Serbia & - & $507,184.96$ & $425,266.24$ \\
\cline { 2 - 5 } & Serbia and Montenegro & 0 & - & 822.8 \\
\cline { 2 - 5 } & Transition economies & 0.5 & 0.211848 & 6.05 \\
\cline { 2 - 5 } & $\begin{array}{c}\text { Developed economies: } \\
\text { Europe }\end{array}$ & 51.76 & 3.146029 & 27.9 \\
\hline
\end{tabular}

Source: http://unctadstat.unctad.org/TableViewer/tableView.aspx

In the analysed period the UN observed the data for Serbia as a part of the union of Serbia and Montenegro, whereas after 2008 the data shown refer to Serbia only.

We have already pointed out that the influence of factors varies from country to country. In order to perceive the influence of factors on FDI in Serbia we have observed 
the influence of GDP, public debt, realistic exchange rate, inflation, export state expenditures, the world GDP growth rate and the country openness. In continuation we demonstrate the regression analysis results - Table 2.

Table 2. The influence of factors on FDI in Serbia - Regression statistics

\begin{tabular}{|c|c|c|c|c|c|c|c|}
\hline Multiple R & 0.999975 & & Df & SS & MS & F & Significance F \\
\hline R Square & 0.999949 & Regression & 9 & 1.159614 & 0.128846 & 2199.569 & 0.016546 \\
\hline Adjusted R & 0.999495 & Residual & 1 & $5.86 \mathrm{E}-05$ & $5.86 \mathrm{E}-05$ & & \\
\hline Standard Error & 0.007654 & Total & 10 & 1.159673 & & & \\
\hline Observations & 11 & & & & & & \\
\hline
\end{tabular}

Source: The Statistical Office of the Republic of Serbia, author's calculation

Based on the coefficient of determination (R-Sq) we conclude that $99.99 \%$ of changes in FDI have been explained by variations of all factors. The constant 10.42 indicates hypothetical value of FDI when all factors equal zero. By means of empirical analysis we have established the probability of correlation existence. The empirical level of $\mathrm{F}$ distribution is 2199.57 and it is higher than critical value (Significance F - 2.88E-05) of $\mathrm{F}$ distribution. The calculated value indicates that the high value of $\mathrm{F}$ distribution is not random, as well as that regression equation is applicable when predicting FDI movement. $\mathrm{T}$ statistics should establish the utility of each coefficient in predicting FDI movement. By means of comparing all absolute values and $t$ - critical point we conclude that the following factors are crucial when forecasting the movement: export, import, inflation, real exchange rate, state expenditures.

By means of correlation matrix we have established the correlation of the stated factors. The strongest correlation of FDI is with GDP, export, import, openness and real exchange rate. The highest correlation coefficient of GDP is with export, import, openness and real exchange rate. The highest correlation coefficient of export and import is openness which is in accordance with the conclusions of Cannonier et al. (2007).

A positive FDI correlation can be noticed in export. The $1 \%$ increase results in FDI growth by 44.23 times, which is in accordance with the results of the research by Cannonier et al. (2007). Precisely Marchant et al. (2002) favored the influence of export on FDI, which agrees with our conclusion about the strongest influence of this factor. We believe that complementary nature of FDI and export is also present, which was explained by Graham (1997). He emphasizes that FDIs are stimuli to export production. The resources realized through export should contribute to the increase of production, 
incomes, technology transfer or, as Campbell (2001) states, resources can be directed towards tertiary sector, by which he implies tourism - Table 3.

Table 3. The influence of GDP, public debt, real exchange rate, inflation, export state expenditures, the world GDP growth rate and the country openness on FDI

\begin{tabular}{|l|l|l|l|l|}
\hline & Coefficients & Stan. Error & $t$ Stat & P-value \\
\hline Intercept & 10.42011 & 1.12737 & 9.242848 & 0.06861 \\
\hline$X_{1}$ GDP & -18.6287 & 0.981108 & -18.9874 & 0.033498 \\
\hline$X_{2}$ DEBT & -9.56877 & 0.4044 & -23.6617 & 0.026889 \\
\hline$X_{3}$ EXP & 44.23821 & 0.796902 & 55.51274 & 0.011467 \\
\hline$X_{4}$ RER & 17.83982 & 1.498165 & 11.90778 & 0.053337 \\
\hline$X_{5}$ INFL & 6.897528 & 0.44007 & 15.67371 & 0.040562 \\
\hline$X_{6}$ GOV & 59.30418 & 4.06593 & 14.58564 & 0.043579 \\
\hline$X_{7}$ IMP & 19.60811 & 0.545318 & 35.95719 & 0.0177 \\
\hline$X_{8}$ WGDP & -41.1808 & 2.067775 & -19.9155 & 0.031939 \\
\hline$X_{9}$ IMPEXP & -6.6073 & 0.843856 & -7.82989 & 0.080869 \\
\hline
\end{tabular}

Source: The Statistical Office of the Republic of Serbia, author's calculation

Similar influence on FDI is exercised by import, so its increase by $1 \%$ contributes to the increase of the FDI by 19.61 times and, apart from export, it is statistically a rather significant factor. We found the confirmation of our findings in Cannonier et al. (2007). Cuadros et al. (2004) pointed out the existence of complementary relationship between FDI and import. Through the research we found positive influence of real exchange rate on FDI, which is not statistically important. A positive effect of real exchange rate was expected and the results obtained are in correlation with the results of Cannonier et al. (2007). The results confirm the hypothesis that a strong and stable currency decreases domestic export, but it increases purchase power abroad and according to Marchant et al. (2002) it probably makes FDIs more attractive. Through the research we identified a positive influence of state expenditures on FDI. The increase of $1 \%$ will lead to the boost in FDI by 59.3 times, contrary to the results obtained by Cannonier et al. (2007). Our research implies a complementary relationship between state expenditures (expressed in GDP percentage) and FDI. The state creates significant investment incentives which contribute to FDI growth. As Blomstrom, Kokko (2003) emphasize, the resources should be directed towards foreign companies, but along with the investment in domestic companies. This way, an increase in national well-being will be achieved. The results indicate positive influence of inflation on FDI which is statistically significant.

Empirical results suggest a negative influence of trade openness on FDI. The increase 
in trade openness, which is expressed as a share of import+export in GDP, results in the drop in FDI. The result corresponds to the conclusion of Cannonier et al. (2007) and implies a "vulnerability to external shocks". Great external trade dependence of Serbia is the confirmation of this hypothesis.

Although a positive influence of GDP on FDI is expected, our results imply a negative influence, which is not statistically important. Since we used GDP per capita as an indicator of the market size or market development (Kolstad, Villanger, 2004) a negative correlation leads to a dilemma. Is the market in Serbia limited and underdeveloped and that is why we obtained a negative correlation dependence, have we used an adequate indicator in measuring FDI movement or are the GDP values per capita low, indicating inefficient market, macroeconomic instability, political uncertainty, corruption, incomplete reform processes, bottlenecks and inefficiency in productions? Our result confirms Choe's (2003) position that the existence of positive correlation, i.e. FDI increase, does not guarantee a GDP increase and vice versa.

The coefficient of the world GDP has been used as a substitution for external income, following the example of Cannonier et al. (2007). Quite the opposite of the results obtained in his study, we have identified a weak negative influence.

At the same time we have observed the effect of factors on GDP. In the equation of factor influence on GDP movement, most of them have an expected value. State expenditures, inflation, real exchange rate and export are statistically significant - Table 4.

Table 4. The effect of factors on GDP - Regression statistics

\begin{tabular}{|c|c|c|c|c|c|c|c|}
\hline Multiple R & 1 & & df & SS & MS & F & Significance F \\
\hline R Square & 0.999999 & Regression & 9 & 0.191988 & 0.021332 & 126726.1 & 0.00218 \\
\hline Adjusted R & 0.999991 & Residual & 1 & $1.68 \mathrm{E}-07$ & $1.68 \mathrm{E}-07$ & & \\
\hline Standard Error & 0.00041 & Total & 10 & 0.191988 & & & \\
\hline Observations & 11 & & & & & & \\
\hline
\end{tabular}

Source: The Statistical Office of the Republic of Serbia, author's calculation

The result of $\mathrm{F}$ distribution shows that this value is not random and that it is significant for predicting GDP movement. The research results show a strong positive influence of state expenditures on GDP movement, which is statistically significant. The increase in state expenditures of 1\% will create a 3.2 time increase in GDP. Export also has a positive influence on GDP movement, so a $1 \%$ increase leads to 2.4 time increase in GDP (Milojevic, Zekic, 2015). Correspondingly, import also influences GDP positively, so the rise of $1 \%$ conditions an increase in GDP by 1.1 times. 
Contrary to the findings of Cannonier et al. (2007) and Chowdhury, Mavrotas (2006), the FDI influence on GDP is negative and statistically unimportant. When FDI influence on the economic growth of a country is analysed, the authors point out limiting factors. Thus, Lensink and Morrissey (2001) indicate that countries with high risk and high level of business insecurity are not attractive for investors. Tian, Lin and Lo (2006) express certain doubts in the significance of FDI for the economic growth in less developed countries and transition countries. FDI and economic development are brought into connection with the level of technologic development, but also political stability, economic reforms and, as Lensink and Morrissey (2006) state, the ability of countries to deal with climatic, agricultural and trade risks. We hold the opinion that macroeconomic and political stability, market size and efficiency are especially significant for attracting FDI and positive influence on GDP. Reform processes, political stability, continuity of economic reforms are necessary, just like, as specified by Tian, Lin Lin and Lo (2006), improving the level of technologic equipment - Table 5.

Table 5. The influence of FDI, public debt, real exchange rate, inflation, export state expenditures, the world GDP growth rate and the country openness on GDP

\begin{tabular}{|l|c|c|c|c|}
\hline & Coefficients & Stan. Error & t Stat & P-value \\
\hline Intercept & 0.556043 & 0.080523 & 6.905424 & 0.091555 \\
\hline X 1 FDI & -0.05353 & 0.002819 & -18.9874 & 0.033498 \\
\hline X 2 DEBT & -0.51336 & 0.006953 & -73.8374 & 0.008621 \\
\hline X 3 EXP & 2.369649 & 0.101797 & 23.27811 & 0.027332 \\
\hline X 4 GOV & 3.18577 & 0.070231 & 45.36122 & 0.014032 \\
\hline X 5 WGDP & -2.21028 & 0.015054 & -146.828 & 0.004336 \\
\hline X 6 IMP & 1.05081 & 0.03878 & 27.09638 & 0.023484 \\
\hline X 7 EXPIMP & -0.35172 & 0.061576 & -5.71199 & 0.110335 \\
\hline X 8 RER & 0.959075 & 0.03446 & 27.83184 & 0.022864 \\
\hline X 9 INFL & 0.370375 & 0.009762 & 37.94005 & 0.016776 \\
\hline
\end{tabular}

Source: The Statistical Office of the Republic of Serbia, author's calculation

\section{Conclusions}

Long-time isolation and the absence of Serbian economy from international economic courses resulted in economic backwardness during the last decade of 20th century, which resulted in a modest foreign capital attraction as a consequence. Considering the lack of domestic resources, FDI is a significant mean of economic recovery and development of Serbian economy. Within the framework of defining development 
policy of Serbia, it is required to identify priority branches and areas towards which FDIs need to be directed. A national strategy should define the type of the necessary FDI and the economy areas that need to be developed. Comparative advantages of Serbian economy should be used, by which we in the first place refer to natural resources and cheap educated labour force.

In order to improve Serbian economy, investments should be directed towards overcoming infrastructural underdevelopment as the main limiting factor of other sectors' development. Communication sector has already drawn significant financial resources, so the IT sector is a development opportunity of Serbia. Comparative advantages of agriculture and food industry should be further improved by investing in the production of organic, safe and healthy food.

The FDIs in the analysed period came from EU countries, countries in the region and the USA in small percentage. The highest amount of FDIs was directed towards the service sector, while the lowest amount was intended for the production of processing industry. The period of intensifying FDIs was in direct connection with the process of privatization; hence, the resources were mostly used for covering budget deficit, public debt and only in a small portion for production improvement. Certain part of FDI came to the country through large trading companies.

The results of the research indicate that the models used are relevant for predicting FDI movement and economic growth. The state largely used FDI resources, invested in Serbia through privatizations, for covering budget deficit and public debt. Through the research we identified the positive influence of export on FDI, where complementary influence is also present. On the other hand, FDIs will affect the augmentation of production and employment, transfer of technologies and knowledge. A complete positive effect of the export on FDI is connected with real exchange rate. A stable currency increases purchase power abroad, which is in correlation with positive influence of import on FDI movement. Stabilization of macroeconomic situation, simulation of export cost the state in terms of state expenditures increase. The programmes created for attracting FDIs in their basis rely on budget stimuli. The obtained empirical results confirm a strong positive influence of state expenditures on FDI movement. The research has identified the influence of GDP per capita, which has been used as an indicator of market size and development on FDI. Contrary to the research results of other authors our study indicates a negative influence. We conclude that the market is undeveloped, inefficient, politically and economically unstable, with corruption present. All the mentioned features do not contribute to GDP growth.

The openness of Serbian economy is not an adequate incentive to FDI movement, which is a situation that is a consequence of our economy's sensitivity to external influences and high import dependence. Encouraging international cooperation, deepening international agreements and a firmer integration would affect FDI and economic growth positively. Although in our study we did not examine the influence of budget deficit, but only government's expenditures the results refer to a direct conclusion. 
Public consumption increase would lead to GDP increase, and precisely GDP increase causes budget deficit increase. Public debt servicing also raises budget deficit and thus affects FDI movement negatively. The state can initiate fiscal income boost, it has to control state expenditures in order to stabilize budget deficit and achieve positive influence on FDI. Further on, we also perceive the influence of factors on economic growth. It has been established that a stable currency and controlled level of prices favour external trade exchange and in that way, affect economic growth positively.

Contrary to theoretical and empirical research of other authors, we have identified a negative influence of FDI on economic growth. In order to eliminate the negative FDI influence, it is necessary to perform a detailed study of budget incentives for domestic and foreign companies. Positive results of FDI on economic growth can be achieved only through fulfilling prerequisites such as highly educated population, fast acceptance of new technologies and cooperation with domestic companies.

\section{Literature}

1. Cuadros, A., Orts, V., Alguacil, M. (2004): Openness and Growth: ReExamining Foreign Direct Investment, Trade and Output Linkages in Latin America. Journal of Development Studies, Vol. 40, No. 4, pp. 167-192.

2. Chowdhury, A., Mavrotas, G. (2006): FDI and Growth: What Causes What?, The World Economy, Vol. 29, No. 1, pp. 9-19.

3. Carkovic, M., Levine, R. (2002): Does foreign direct investment accelerate economic growth?, University of Minnesota Department of Finance. Working Paper, Available at: http://ssrn.com/abstract=314924; $\underline{\text { http://dx.doi.org/10.2139/ssrn.314924 }}$

4. Marchant, M. A., Manukyan, T., Koo, W. (2002): International Trade and Foreign Direct Investment: A Focus on the Free Trade Area of the Americas, Available online: http://cnas.tamu.edu/publications/powerpoint/papers/Marchant.pdf (accessed on 25.07.2013)

5. Graham, E. M. (1997): Working Together: Foreign Direct Investment and Trade, Economic Reform Today, Globalization, Trade and Democracy, Number 3.

6. Graham, E., Wada, E. (2002): Foreign direct investment in China: effects on growth and economic performance, Institute for International Economics, Working Paper, (01-03). Available online: http://papers.ssrn.com/sol3/papers.cfm?abstract $\underline{\mathrm{id}=300884}$ (accessed on 11.05.2013)

7. Blomstrom, M., Kokko, A. (2003): The Economics of Foreign Direct Investment Incentives. No. w 9489, National Bureau of Economic Research,

8. Choe, J.I. (2003): Do foreign direct investment and gross domestic investment promote economic growth? Review of Development Economics, Vol. 7, No. 1, pp. 44-57.

9. Brock, G. (2005): Regional Growth in Russia During the 1990s-What Role did FDI Play?, Post-communist economies, Vol. 17, No. 3, pp. 319-329. 
10. Nunnenkamp, P., Schweickert, R., Wiebelt, M. (2007): Distributional effects of FDI: how the interaction of FDI and economic policy affects poor households in Bolivia, Development policy review, Vol. 25, No. 4, pp. 429-450.

11. Asiedu, E. (2006): Foreign direct investment in Africa: The role of natural resources, market size, government policy, institutions and political instability, The World Economy, Vol. 29, No. 1, pp. 63 - 77.

12. Hansen, H., Rand, J. (2006): On the causal links between FDI and growth in developing countries, The World Economy, Vol. 29, No. 1, pp. 21-41.

13. Bengoa, M., Sanchez-Robles, B. (2003): Foreign direct investment, economic freedom and growth: new evidence from Latin America, European journal of political economy, Vol. 19, No. 3, pp. $529-545$.

14. Hermes, N., Lensink, R. (2003): Foreign direct investment, financial development and economic growth, The Journal of Development Studies, Vol. 40, No. 1, pp. 142-163.

15. Chen, C., Chang, L., Zhang, Y. (1995): The role of foreign direct investment in China's post-1978 economic development, World development, Vol. 23, No. 4, pp. 691-703.

16. Raičević, V., Ignjatijević, S. (2011): Strane direktne investicije kao podsticaj razvoju privrede Srbije, Međunarodni naučni skup o ekonomskom razvoju $i$ životnom standardu, EDASOL 2011, Banja Luka: Univerzitet APEIRON, 439-448. Available online: http://www.edasol-au.com/sites/zbornikradova.pdf (accessed on 15.07.2012)

17. Ignjatijević, S., Milojević, I., Cvijanović, G., Jandrić, M. (2015): Balance of Comparative Advantages in Processed Food Sector of the Danube Countries, Sustainability, Vol. 7, No. 6, pp. 6976 - 6993.

18. Cannonier, C., Francis, B., Lorde, T. (2007): Foreign Direct Investment and Trade in the Eastern Caribbean Currency Union, Journal of Eastern Caribbean Studies, Vol. 32, No. 3, pp. $23-49$.

19. Kolstad, I., Villanger, E. (2004): Determinants of Foreign Direct Investments in Services. CMI Working Paper WP 2004:2, Available online: http://bora.cmi. no/dspace/bitstream/10202/122/1/Working\%20paper\%20WP\%202004-2.pdf, (accessed on 11.06.2014)

20. Flexner, N. (2000): Foreign direct investment and economic growth in Bolivia, 1990-1998. Economic Policy Division, Central Bank of Bolivia, La Paz-Bolivia, Available online: http://econwpa.wustl.edu/eps/mac/papers/0309/0309009.pdf (accessed on 15.04.2013)

21. UNCTAD, Available online: http://unctad.org/en/Pages/Home.aspx, (accessed on 14.06.2014)

22. Campbell, T. (2001): Foreign Direct Investment (FDI) Inflows and their Impact on Barbados' Current Account: Implications for Substitute/Complements 
Between FDI and Exports, Research Department, Central Bank of Barbados. Presented at Canadian Economic Association (CEA) 2001 Annual Meeting, McGill University, Montreal, Canada.

23. Lensink, R., Morrissey, O. (2001): Foreign direct investment: flows, volatility and growth in developing countries, University of Groningen.

24. Praća, N. (2015): Recesija i njeno prevazilaženje u uslovima savremenog kapitalizma, Oditor, no. 10, pp. 23-33.

25. Tian, X., Lin, S., Lo, V. I. (2004): Foreign Direct Investment and economic performance in transition economies: Evidence from China, Post-Communist Economies, Vol. 16, No. 4, pp. 497-510.

26. Lensink, R., Morrissey, O. (2006): Foreign Direct Investment: Flows, Volatility, and the Impact on Growth, Review of International Economics, Vol. 14, No. 3, pp. 478-493.

27. The Statistical Office of the Republic of Serbia, Available online: http:// webrzs.stat.gov.rs/WebSite/ (accessed on 15.07.2014)

28. Milojevic, I., Zekic, M. (2015): Organizaciona struktura preduzeca kao pretpostavka konsolidacije bilansa, Oditor, Vol. 12, No. 1, pp. 22-28. 


\title{
FINANSIJSKA ANALIZA UTICAJA STRANIH DIREKTNIH INVESTICIJA NA EKONOMSKI RAST ZEMALJA U RAZVOJU
}

\author{
Božidar Raičevićt, Svetlana Ignjatijevićs ${ }^{5}$, Ivan Milojević ${ }^{6}$
}

\begin{abstract}
Apstrakt
Predmet istraživanja u ovom radu je izvršenje empirisjke analize uticaja stranih direktnih investicija (FDI) na ekonomski rast sa ciljem određivanja faktora koji doprinose prevazilaženju problema. Rezultati istraživanja upućuju na realističan kurs, uvoz i izvoz, kao i to da su javni rashodi značajni za predviđanje kretanja ekonomskog rasta i imaju značajan pozitivan uticaj na kretanje FDI. Empirijska analiza, uprkos očekivanjima, je pokazala da FDI, javni dug i otvorenost imaju negativan uticaj na ekonomski rast u slučaju Republike Srbije. U narednom periodu Srbija mora da smanji udeo deficita u BDP-u i kontroliše javni dug. Srbija mora da obrati posebnu pažnju poboljšanju investicionog ambijenta i podstakne izvozno orijentisanu proizvonju, dok je upravljanje finansijama i nastavljanje reformskog procesa osnova za uspostavljanje održivog razvoja zemlje, sa održivim korišćenjem raspoloživih resursa.
\end{abstract}

Ključne reči: strane direktne investicije, ekonomski rast, izvoz, Republika Srbija, održivi razvoj

4 Profesor emeritus, dr Božidar Raičević, Slobomir P univerzitet, Ulica Svetog Save br. 76, Doboj, BiH, E-mail: boskoraicevic@gmail.com

5 Vanredni profesor, dr Svetlana Ignjatijević, FIMEK Novi Sad, Cvećarska ulica br. 2, 21000 Novi Sad, Srbija, E-Mail: ceca@fimek.edu.rs

6 Redovni profesor, dr Ivan Milojević, Univerzitet Odbrane, Vojna Akademija, Ulica Pavla Jurišića Šturma br. 33, 11000 Beograd, Srbija, Telefon: +381 606699 177, E-Mail: drimilojevic@gmail.com

EP 2016 (63) 2 (649-663) 